\title{
TEKNOLOGI INFORMASI DAN KOMUNIKASI BERUPA E-BOOK BERBASIS \\ KEARIFAN LOKAL DALAM PENGEMBANGAN BAHAN AJAR BAHASA DAN \\ SASTRA
}

\author{
Hainur Anisa
}

Pendidikan Bahasa Indonesia

Pascasarjana Universitas Negeri Medan

\begin{abstract}
Abstrak
Pengembangan materi merupakan dasar untuk belajar dan sebuah tanggung jawab praktis. Sebagai suatu dasar, materi mempelajari prinsip dan prosedur dalam mendesainnya, implementasi dan evaluasi materi pembelajaran bahasa. Mengkaitkan dengan kearifan lokal akan membuat siswa lebih mengenali budayanya masing-masing. Perkembangan zaman serba teknologi menjadi salah satu contoh perkembangan zaman yang tentu tidak dapat ditepis oleh siapapun. Para pelajar yang hidup pada era IT ini tentu akan merasa lebih tertarik dengan pembelajaran yang berbasis IT. rekayasa ini dimuculkan ide yang berkitan dengan pengembangan bahan ajar dan perkembangan zaman. Mengembangkan bahan ajar dalam bentuk buku digital pada masa sekarang ini merupakan pilihan yang tepat dilakukan para guru karena akan membuat siswa lebih tertarik. Kebutuhan dalam dunia pendidikan sangatlah kompleks mulai dari kebutuhan sumber ilmu, yaitu buku, guru yang handal, tempat yang memadai, dan kebutuhan penunjang lainnya. E-book adalah salah satu alternatif yang cukup baik karena sifatnya yang digital sehingga tidak menggunakan kertas dan hanya memerlukan seperangkat device yang dapat membacanya seperti HP, komputer, laptop, dan device-device lainnya. Dalam E-book terdapat beberapa format buku yang dapat digunakan. E-book ini nantinya akan berupa buku yang di dalamnya terdiri dari video, gambar, teks, audio, animasi, dan evaluasi berupa soal-soal yang menarik berbasis kearifan lokal.
\end{abstract}

Kata kunci: Bahan ajar, kearifan lokal, digital, e-book

\section{A. PENDAHULUAN}

Pembelajaran bukan kata yang asing bagi masyarakat. Widiasworo (2017:15) mendefinisikan pembelajaran sebagai suatu sistem atau proses membelajarkan subjek didik atau pembelajar yang direncanakan atau didesain, dilaksanakan, dan dievaluasi secara sistematis agar pelajar dapat mencapai tujuan pembelajaran dengan efektif dan efisien.

Guru dianggap telah melakukan pembelajaran apabila telah terjadi perubahan perilaku pada pelajar. Hal ini berkaitan dengan pembelajaran efektif. Pembelajaran dikatakan sebagai pembelajaran efektif apabila pembelajaran itu tidak semata-mata memberikan dampak 
instruksional, tetapi juga memberi dampak pengiring positif. Lalu bagaimana menciptakan pembelajaran yang efektif dalam pembelajaran bahasa dan sastra?

Para pakar menyatakan bahwa pembelajaran harus didesain berdasarkan kebutuhan peserta didik. Pendapat tersebut didukung oleh Maley (dalam Azarnoosh, 2016: 11) yang menyatakan bahwa materi itu selalu berkembang. Materi merupakan bagian dari seluruh konteks pembelajaran bahasa untuk apa bahasa itu dan bagaimana orang-orang belajar bahasa. Materi hanya sebagian kecil dari pembelajaran, namun memiliki peranan yang sangat penting karena materi itu akan digunakan oleh guru, dipelajari oleh siswa, ditentukan penilaian hasilnya, dikaitkan dengan keadaan ekonomi dan kebudayaan yang ada di sekitar siswa. Kebudayaan tersebut berupa perkembangan teknologi saat ini. Para pelajar yang hidup pada era IT akan merasa antusias dengan pembelajaran yang berbasis IT. Pengembangan bahan ajar sangat diperlukan, tanpa terkecuali pada pembelajaran bahasa. Pembelajaran berbasis IT ini dapat diwujudkan dengan penggunaan digital dalam pembelajaran.

Derewianka (dalam Tomlinson, 2003: 199) menegaskan bahwa bahan ajar berbasis digital itu dapat berupa hypermedia, multimedia, dan media komunikasi. Dengan menggunakan bahan ajar berbasis media seperti yang telah dijelaskan sebelumnya, pertama sekali kita akan melihat bagaimana bahan ajar digital dapat meningkatkan keinginan pelajar untuk membaca, menulis, dan akhirnya kita akan melihat bagaimana guru dapat menciptakan lingkungan belajar yang kreatif dan inovatif. Dengan demikian, outcome dari pembelajaran bahasa dan sastra Indonesia benar-benar dirasakan oleh peserta didik.

Berbicara tentang kebutuhan siswa seperti yang telah dijelaskan sebelumnya, pengembangan bahan ajar bahasa dan sastra Indonesia akan lebih bermanfaat jika mengusung tema kearifan lokal. Kearifan lokal tampaknya seperti obat mujarab (panacea) dalam upaya melihat kompleksitas permasalahan yang dihadapi manusia modern akibat perilaku yang tidak rasional dalam menaklukkan alam. Kegagalan manusia modern dalam mengelola kompleksitas permasalahan yang dihadapi memaksanya untuk mencari pilihan-pilihan (alternatives). Pilihan-pilihan tersebut menunjukkan adanya satu jalan buntu dan mungkin dapat pula dikatakan frustasi sehingga memaksanya untuk menengok kembali pada nilai-nilai budaya yang sudah lama mereka tinggalkan dan malahan boleh jadi struktur dan nilai budaya tersebut mungkin pula telah rusak oleh perilaku manusia itu sendiri. Secara sederhana kearifan lokal dapat didefinisikan sebagai kebijaksanaan atau nilai-nilai luhur yang terkandung dalam kekayaan budaya lokal. Namun ada kalanya kearifan lokal boleh jadi merupakan slogan " kembali ke alam" (back to nature) atau natura magistra dan banyak sekali interpretasi yang diberikan oleh para pengguna istilah tersebut seperti halnya juga tentang 
pengertian kebudayaan.

Dengan mengangkat kearifan lokal dalam bahan ajar, siswa diharapkan dapat mengenali budayanya dan nilai-nilai di dalamnya. Pembinaan karakter yang diajarkan di sekolah juga dapat terlaksana bila siswa memahami betul setiap nilai-nilai budayanya. Hal ini diyakini karena setiap siswa memiliki budaya masing-masing dan budaya tersebut sangat dekat dengan mereka.

\section{B. KAJIAN TEORI}

\section{Konsep Pengembangan Materi}

Banyak orang menghubungkan materi pembelajaran bahasa dengan buku pelajaran karena hal tersebut menjadi cara untuk mempelajari materi. Bagaimanapun, buku ini digunakan oleh guru dan pelajar sebagai fasilitas dalam mempelajari bahasa. Tomlinson (2011: 2) menyatakan bahwa materi ajar seyogiyanya dapat berupa video, DVD, email, youtube, kamus, buku gramatikal, pembaca, LKS atau lembaran latihan yang diperbanyak. Selain itu juga dapat berupa surat kabar, paket makanan, fotografi, bincang-bincang dengan mengundang penutur asli, lembar latihan menulis dalam bentuk kartu atau diskusi antar pelajar. Tomlinson (2011:2) kembali menegaskan bahwa semua hal di atas akan berguna untuk pelajar mengingat bahwa materi dapat menjadi pelajaran dalam memberikan informasi melalui bahasa, semakin menjadikan pelajar terbuka dalam menggunakan bahasa, dapat menjadi pancingan bagi pelajar untuk menstimulus penggunaan bahasa, atau dapat dijadikan fasilitas untuk memecahkan masalah.

'Pengembangan materi merupakan dasar untuk belajar dan sebuah tanggung jawab praktis. Sebagai suatu dasar, materi mempelajari prinsip dan prosedur dalam mendesainnya, implementasi dan evaluasi materi pembelajaran bahasa' (Tomlinson 2001: 66). Sebagai tanggung jawab praktis, materi mengarah pada apapun yang diselesaikan oleh penulis, guru atau pelajar untuk memberikan pengetahuan dalam input bahasa, untuk mengeksploitasi pengetahuan yang maksimal dan untuk menstimulus pencapaian hasil. Dengan kata lain, penerimaan informasi tentang pengalaman dari bahasa didesain untuk mempromosikan pembelajaran bahasa (Tomlinson 2001:66).

Para pakar menyatakan bahwa pembelajaran harus didesain berdasarkan kebutuhan peserta didik. Hal ini tentu berkaitan dengan perkembangan zaman. Untuk itu, tentu tidak heran jika banyak para peneliti, baik guru, dosen, maupun mahasiswa memberikan kontribusi dengan menyajikan inovasi, model pembelajaran, media, strategi, dan pendekatan. Pendapat 
tersebut didiukung oleh Maley (dalam Azarnoosh, 2016: 11) yang mengatakan bahwa materi itu selalu berkembang. Materi merupakan bagian dari seluruh konteks pembelajaran bahasa berdasarkan filosofinya tergantung pada pemikiran untuk apa bahasa itu dan bagaimana orang-orang belajar bahasa sehingga materi tersebut berbeda. Materi itu hanya sebagian kecil dari pembelajaran, namun memiliki peranan yang sangat penting karena materi itu akan digunakan oleh guru, dipelajari oleh siswa, disusun berdasarkan kurikulum dan silabus, ditentukan alokasi waktu dan penilaian hasil pembelajaran, dikaitkan dengan keadan ekonomi dan kebudayaan yang ada di sekitar siswa. Ketika hendak menyusun suatu materi, sering dianggap sebagai sesuatu yang mudah, namun nyatanya memerlukan banyak faktor. Jadi kita tidak dapat memisahkan materi dari permasalahan bahasa dan pembelajaran bahasa.Perkembangan zaman serba teknologi menjadi salah satu contoh perkembangan zaman yang tentu tidak dapat ditepis oleh siapapun. Para pelajar yang hidup pada era IT ini tentu akan merasa lebih tertarik dengan pembelajaran yang berbasis IT. Pengembangan bahan ajar sangat diperlukan dalam hal ini tanpa terkecuali pada pembelajaran bahasa. Pembelajaran berbasis IT ini dapat diwujudkan dengan penggunaan digital dalam pembelajaran. Derewianka (dalam Tomlinson, 2003: 199) menyatakan bahwa bahan ajar digital mengacu pada proses belajar berbasis digital sehingga peserta didik dapat mengakses sumber informasi bahan ajar dengan komputer.

Pembelajaran Digital dapat pula diartikan sebagai sebuah proses pembelajaran yang dilakukan melalui network (jaringan komputer), biasanya lewat internet atau intranet. Dengan fasilitas internet, Pembelajaran Digital tidak tergantung pada pengajar, karena akses informasi (knowledge) lebih luas dan lengkap, sehingga pembelajar dapat belajar kapan saja dan dimana saja.

Dalam teknologi Pembalajaran Digital, semua proses pembelajaran yang biasa didapatkan di dalam sebuah kelas dapat dilakukan secara live namun virtual. Artinya pada saat yang sama seorang pengajar mengajar di depan sebuah komputer yang ada di suatu tempat, sedangkan pembelajar mengikuti pembelajaran tersebut dari komputer lain di tempat yang berbeda.

Secara umum terdapat dua persepsi dasar tentang Pembelajaran Digital yaitu: Electronic based e-learning, yaitu pembelajaran yang memanfaatkan teknologi informasi dan komunikasi, terutama perangkat yang berupa elektronik. Artinya, tidak hanya internet, melainkan semua perangkat elektronik seperti film, video, kaset, OHP, Slide, LCD Projector, tape dan lain-lain sejauh menggunakan perangkat elektronik. Internet based, yakni pembelajaran yang menggunakan fasilitas internet yang bersifat online 
sebagai instrumen utamanya. Dalam hal ini, Pembelajaran Digital bukanlah pembelajaran yang dilakukan secara offline (tanpa jaringan internet), tetapi Pembelajaran Digital adalah pembelajaran yang dilakukan secara online yang harus difasilitasi komputer yang terhubung dengan internet. Artinya pembelajar dalam mengakses materi pembelajaran tidak terbatas jarak, ruang dan waktu, bisa dimana saja dan kapan saja (any where and any time).

Pengembang materi ajar dapat berupa menulis buku teks, menceritakan sebuah cerita, membawa iklan ke kelas, mengekspresikan opini, mencontohkan penggunaan bahasa atau pembacaan puisi. Dengan demikian, guru/ pengembang materi ajar dapat mengetahui bagaiamana membuat prinsip sehingga guru tahu bagiamana bahasa dapat menjadi pembelajaran yang efektif (Tomlinson, 2011:2).

Bila dikaitkan dengan perkembangan zaman dengan kebutuhan siswa, menciptakan suatu pengembangan bahan ajar berupa buku digital merupakan salah satu langkah yang perlu dilakukan oleh guru. Di samping dapat meningkatkan minat belajar siswa, buku digital ini juga dapat membantu siswa dapat berpikir kreatif dan inovatif dalam menciptakan pembelajaran yang efektif.

\section{Prinsip dan Proses Pengembangan Bahan Ajar}

Dalam mengembangkan bahan ajar bahasa Indonesia terdapat beberapa prinsip dan prosedur. Tomlinson (2011: 16) mengatakan bahwa prinsip pengembangan materi ajar, yaitu:

1. Materi harus memberikan dampak.

2. Materi harus membawa kemudahan kepada para pelajar.

3. Materi harus membantu pelajar menjadi percaya diri,

4. Apa yang dipelajari harus berguna dan relevan untuk pelajar.

5. Materi harus dibutuhkan dan memudahkan pelajar dalam pengembangan diri.

6. Pelajar harus siap untuk memperoleh poin pengajaran.

7. Materi harus mengekspos pelajar untuk menggunakan bahasa secara spontan.

8. Perhatian pelajar harus digambarkan pada tanda-tanda bahasa.

9. Materi harus mengarahkan pelajar pada kesempatan untuk mencapai target bahasa untuk mencapai tujuan komunikasi.

10. Materi harus membawa efek positif pengajaran yang belum diterima.

11. Materi harus disesuaikan dengan gaya belajar pelajar yang berbeda-beda.

12. Materi harus disesuaikan dengan perbedaan pelajar dalam sikap yang efektif.

13. Materi harus mampu membuat siswa hening pada awal pembelajaran. 
14. Materi harus memaksimalkan potensi belajar dengan semangat.

15. Materi harus tidak terlalu mengontrol praktik.

16. Materi harus mengarah pada kesempatan pada pengaruh hasil.

Setelah membahas tentang prinsip dalam mengembangan materi ajar, selanjutnya akan dibahas tentang prosedur dalam pengembangan materi ajar. Maley (Azarnoosh, 2016: 21) menjelaskan beberapa prosedur pengembangan materi ajar, yaitu:

\section{Proses Level Macro}

Pada tahap, proses utamanya adalah:

- Desain pada keseluruhan krangka kerja Bagian ini diambil dari silabus yang dibuat oleh Kementrian Pendidikan (The Common European Framework, Morrow, 2004). Suatu pendekatan telah ditetapkan,kemudian unsur berbeda dikemas akan merincikan materi. Normalnya,beberapa kombinasi dari area pengikut akan menjelaskan lebih spesifik tentang cara pengucapan, kosakata, tata bahasa, fungsi, empat keterampilan berbahasa, tipe teks, berpikir kritis, keterampilan, tema atau topik, situasi/konteks, dan lain-lain. Pada bagian ini penyusun materi akan menyusun dengan baik setiap aktivitas yang digunakannya (bercerita, membaca ekstensif).

- Memilih teks dan aktivitas

Pemilihan teks merupakan bagian yang paling utama dalam proses pengembangan materi. Kriteria pemilihannya akan menyangkut tentang ketertarikan intrinsik, relevansi dengan pengalaman pelajar, usia, durasi, kesulitan/kompleksitas linguistik, , kerumitan kognitif, kebudayaan, potensi pembelajaran bahasa, daya tarik estetis, dan sesuatu yang paling menaril/memorial.

Hal ini akan menjadi permasalahan seperti hak cipta dan akses terhadap teks. Saat ini menyebarnya ketersediaan materi dalam suatu situs menghapuskan permasalahan tersebut. Para penyusun materi akan membuat dengan jelas nama pembuatan teksnya.

\section{Proses Micro-Level}

a. Hadfield (Azarnoosh, 2016: 22) mengidentifikasi lima tingkatan dalam proses menulis, yaitu:

Tingkat 1: Memilih tipe aktivitas.

Tingkat 2 : Tujuan dan aktivitas yang layak (memastikan aktivitas yang sesuai dengan tujuan yang baik).

Tingkat 3: Penyusunan pemecahan masalah. 
Tingkat 4: Menulis materi siswa.

Tingkat 5: Menyusun rubrik prosedur/ penulisan.

b. Maley (Azarnoosh, 2016: 22) menawarkan sebuah peta pembangkit aktivitas. Bagian yang terdiri dari susunan input menggambarkan semua kemungkinan ketersediaan input. Hal ini merupakan proses yang dapat dipalikasikan pada beberapa input. Akhirnya, hasil berkaitan dengan aktivitas seperti pencapaian hasil yang diperoleh.

\section{Tingkat Pengaplikasian}

a. Input/ masukan

Materi harus menggambarkan sumber manusia yang tak terbatas. Seluruh aktivitas dapat diperkaya oleh pandangan terhadap pelajar. Dalam pemilihan tema/topik, kita harus berangkat dari hal-hal yang umum. Hal itu dapat berupa olahraga, hobi, belanja, festival kebudayaan, dan sebagainya.

Teks

Teks merupakan bagian dasar dari materi. Kita dapat melatih kreativitas melalui pilihan beberapa teks, teristimewa pada yang berkaitan dengan teks sastra, hal itu dapat mengekspos kekreatifan pelajar dalam menggunakan bahasa (Duff \& Malley (Azarnoosh,2016:23)).

b. Proses

Proses dapat meningkatkan kualitas kreativitas materi. Berikut akan dijelaskan lebih mendetail tentang lima ketegori tingkatan, yaitu:

$\checkmark \quad$ Istilah umum

Penggunaan waktu dapat dihendel dengan kreatif melalui pengaturan waktu yang sesuai dalam beberapa aktivitas (Davis \& Rinvolucri (dalam Azarnoosh, 2016: 25)). Membiarkan siswa banyak melakukan banyak tes, atau dengan melatih siswa mengatur waktunya sendiri sama dengan memunculkan keistimewaan hasil.

$\checkmark$ Manajemen

Kreativitas dalam memanajemen rutinitas dan pengajaran dapat digantikan dengan petunjuk non-verbal. Pelajar dengan cepat akan belajar menggunakan gestur.

c. Hasil

Input dan proses berkaitan dengan produk hasil tetapi hal itu tidak dapat dihasilkan dengan formula yang kompleks. Hasil pedagogi dapat melewati 
kepercayaan tradisional dalam tes dan penugasan dalam bentuk portofolio dan jurnal untuk mengevaluasi pelajar (Phuong (Azarnoosh, 2016:26)).

Secara luas, hasil pendidikan muncul dari interaksi kreatif dari input dan proses dan termasuk pula pemahaman tentang kebudayaan, menerima kebijaksanaan atau informasi dengan kritis, mampu memecahkan masalah, dan mampu mengatur waktu dalam mengolah keterampilan. Pada kehidupan sosial, pelajar dapat meningkatkan kepercayaan diri dan lebih bertanggung jawab dan mampu bekerja sama untuk menciptakan suasana belajar yang positif (Hadfield (dalam Azarnoosh, 2016: 27)).

\section{GAGASAN}

Berdsarkan penjelasan di atas, maka dalam rekayasa ini dimuculkan ide yang berkitan dengan pengembangan bahan ajar dan perkembangan zaman. Mengembangkan bahan ajar dalam bentuk buku digital pada masa sekarang ini merupakan pilihan yang tepat dilakukan para guru karena akan membuat siswa lebih tertarik.

Kebutuhan dalam dunia pendidikan sangatlah kompleks mulai dari kebutuhan sumber ilmu, yaitu buku, guru yang handal, tempat yang memadai, dan kebutuhan penunjang lainnya. E-book adalah salah satu alternatif yang cukup baik karena sifatnya yang digital sehingga tidak menggunakan kertas dan hanya memerlukan seperangkat device yang dapat membacanya seperti HP, komputer, laptop, dan device-device lainnya. E-book adalah salah satu bentuk usaha untuk melestarikan literatur berbentuk buku yang banyak jumlahnya dan memerlukan biaya perawatan yang mahal maka untuk dapat melestarikan literatur tersebut hanya dengan melakukan transfer buku ke bentuk E-book.

Dalam E-book terdapat beberapa format buku yang dapat digunakan. E-book ini nantinya akan berupa buku yang di dalamnya terdiri dari video, gambar, teks, audio, animasi, dan evaluasi berupa soal-soal yang menarik berbasis kearifan lokal. Penggunaan Ebook dalam pembelajaran bahasa diduga akan sangat efisien. Hal ini dikarenakan dalam buku tersebut akan dapat ditampilkan keempat keterampilan berbahasa dengan tampilan yang menarik dan ada dalam satu buku. Selain itu, buku ini akan sangat efisien untuk dibawa ke mana saja dan dibaca di mana saja. Buku digital ini akan membuat pelajar lebih mudah memahami teori bahasa, praktik bahasa, dan evaluasi bahasa.

Dengan menggunakan E-book ini , penulis mengharapkan pembelajaran bahasa tidak lagi monoton dan kurang menarik tetapi menjadi ajang untuk pemecah masalah melalui ide- 
ide yang berkaitan dengan kearifan lokal yang dibahasakan. Hal tersebut sudah sangat sesuai dengan penjelasan dalam kajian teori di atas. Pengembangan bahan ajar harus sesuai dengan kebutuhan siswa dan dapat berbasis digital. Pengembangan bahan ajar berupa E-book ini tentu harus disusun berdasarkan prinsip dan proses pengembangan bahan ajar yang telah dijelaskan sebelumnya.

\section{SIMPULAN}

Materi itu hanya sebagian kecil dari pembelajaran, namun memiliki peranan yang sangat penting karena materi itu akan digunakan oleh guru, dipelajari oleh siswa, disusun berdasarkan kurikulum dan silabus, ditentukan alokasi waktu dan penilaian hasil pembelajaran, dikaitkan dengan kebudayaan yang ada di sekitar siswa. Ketika hendak menyusun suatu materi, seringa dianggap sebagai sesuatu yang mudah, namun nyatanya memerlukan banyak faktor.

Penggunaan E-book dalam pembelajaran bahasa diduga akan sangat efisien. Hal ini dikarenakan dalam buku tersebut akan dapat ditampilkan keempat keterampilan berbahasa dengan tampilan yang menarik dan ada dalam satu buku. Selain itu, buku ini akan sangat efisien untuk dibawa ke mana saja dan dibaca di mana saja. Buku digital ini akan membuat pelajar lebih mudah memahami teori bahasa, praktik bahasa, dan evaluasi bahasa. Pengembangan bahan ajar menggunakan E-book juga telah sesuai dengan kebutuhan siswa dan dapat berbasis digital. Pengembangan bahan ajar berupa $E$-book ini tentu harus disusun berdasarkan prinsip dan proses pengembangan bahan ajar yang telah dijelaskan sebelumnya.

\section{DAFTAR RUJUKAN}

Azarnoosh, Maryam. 2016. Issues in Materials Development. Rotterdam:Sense Publishers.

Tomlinson, Brian. 2011. Materials Development in Language Teaching. UK: Cambridge University Press.

Bloomsbury.

Widiasworo, Erwin. 2017. Inovasi Pembelajaran Berbasis Life Skill dan Entrepreneurship. Yogyakarta: Ar-Ruzz Media. 